\title{
Distribution of Chromium, Copper, Lead and Zinc in Soil From Kimanis, Papar, Sabah
}

\author{
Hazerina Pungut, Baba Musta, Nurul Fadzilah Asgari \\ School of Science and Technology, Universiti Malaysia Sabah, Jalan UMS, 88400 Kota Kinabalu, Sabah, Malaysia
}

Received 5 January 2013, Revised 15 March 2013, Accepted 19 April 2013, Available online 21 May 2013

\begin{abstract}
This paper discusses the distribution of selected heavy metals namely chromium (Cr), copper $(\mathrm{Cu})$, lead $(\mathrm{Pb})$ and zinc $(\mathrm{Zn})$ in soil from Kimanis, Papar, Sabah. Fourteen soil samples were collected from soil originated from sedimentary rock of Crocker Formation and Quaternary deposit. The Crocker Formation consists of thick sandstone unit and inter-bedded sandstone and shale unit with the age of Late Eocene to Early Miocene. The physicochemical analysis of soil include the $\mathrm{pH}$ value, moisture content, organic content and particle size. Soil of Crocker Formation were classified as sandy loam and sandy clay loam, while Quaternary deposit were classified as sand, sandy loam, sandy clay loam and clay with loam. The result of analysis shows the soils were acidic with $\mathrm{pH}$ values range from 3.06-5.65. Organic matter content ranges from $0.98 \%-7.63 \%$ and moisture content were $13.8 \%$ $60.51 \%$. All heavy metals were analyzed using ICP-OES. The result of analysis indicated that $\mathrm{Zn}$ shows the highest value then followed by $\mathrm{Cu}, \mathrm{Pb}$ and Cr. Soil sample from Crocker Formation show significantly high Zn and Cu content, where SC6 and SC7 have Zn value of $274.36 \mu \mathrm{g} / \mathrm{g}$ and $127.82 \mu \mathrm{g} / \mathrm{g}$ respectively, whereas $127.98 \mu \mathrm{g} / \mathrm{g}$ of $\mathrm{Cu}$. The distribution of heavy metals in soil samples are controlled by the mobility and leaching process during chemical weathering and also adsorption by clay particles and organic matter as well as the human activities within the area.
\end{abstract}

| Heavy metals | Physical properties | sandstone | quaternary deposit |

( 2013 Ibnu Sina Institute. All rights reserved. http://dx.doi.org/10.11113/mjfas.v9n4.107

\section{INTRODUCTION}

Heavy metals, or trace metals, is a term applied to a large group of trace elements [1]. Pollution of the natural environment by heavy metals is a universal problem because these metals are indestructible and most of them have toxic effects on living organisms, when permissible concentration levels are exceeded [2]. Exposure of heavy metals to human was through contaminated soil as well as consumption of contaminated food and drinking water. Heavy metals could cause serious health problem and in some cases could lead to death. Their total load in sediments depends on the myriad of factors including the local geology, human activities and the ecological health of the system [3]. This study focuses on the distribution of selected heavy metals chromium (Cr), copper (Cu), lead $(\mathrm{Pb})$ and zinc $(\mathrm{Zn})$ in soil taken from Kimanis, Papar, Sabah (Figure 1).

The rock unit in the study area comprise of Crocker Formation aged Late Eocene to early Miocene and Quaternary deposit. The Crocker Formation was made of clastic sedimentary rocks showing turbidite deposit sequence that suggests the depositional environment was deep marine. It consists of thick sandstone unit and interbedded sandstone and shale unit, whereas Quaternary Deposits were made of sand, gravel, silt, mud and organic material (Figure 2) [4].

\section{EXPERIMENTAL}

\subsection{Materials, method and instruments}

A total of 14 soil samples from Crocker Formation (SC1-SC7) and Quaternary deposits (SQ1-SQ7) in Kimanis, Papar, Sabah (Figure 3) were gathered and analysed for their heavy metals using Inductively Coupled Plasma Optical Emission Spectrometry (ICP-OES). Selected heavy metals were analysed namely chromium $(\mathrm{Cr})$, copper $(\mathrm{Cu})$, lead $(\mathrm{Pb})$ and zinc $(\mathrm{Zn})$. Additional test on soil samples were done to study their $\mathrm{pH}$, moisture content, organic content and particle size distribution.

\subsection{Heavy Metals Analysis}

About $14 \mathrm{ml}$ of Aqua Regia was added to $1.0 \mathrm{~g}$ soil sample and being left overnight. Then, solution was heated on sand bath until the solution decreases to $10 \mathrm{ml}$ and cooled before adding another $4 \mathrm{ml}$ of Aqua Regia. The solution was heated again on sand bath for 30 minutes. After it cooled, stir the solution then filtered into $50 \mathrm{ml}$ bottle and analysed using ICP-OES Perkin Elmer Optima $5300 \mathrm{DV})$. The heavy metals concentration obtained were calculated using the following formula:

Heavy metals concentration $(\mathrm{ppm})=\frac{\mathrm{A} \times \mathrm{V} \times \mathrm{dF}}{\mathrm{m}} \times 100$ 


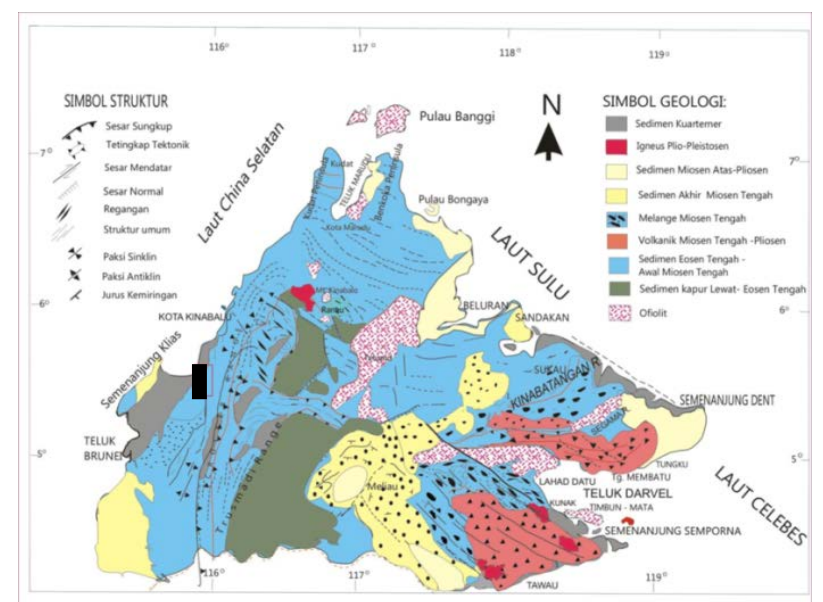

Fig. 1 Geological map of Sabah showing the location of study area.

\begin{tabular}{|c|c|c|c|c|}
\hline MY & \multicolumn{2}{|l|}{ Epoch } & Rock Unit & Characteristics \\
\hline 0 & Quaternary & & $\begin{array}{l}\text { Quaternary } \\
\text { Deposits }\end{array}$ & $\begin{array}{l}\text { Sand, gravel, silt, mud } \\
\text { and organic material }\end{array}$ \\
\hline 5 & Pliocene & & & \\
\hline $\begin{array}{l}10 \\
15 \\
20\end{array}$ & MIOCENE & $\begin{array}{c}\text { Late } \\
\text { Middle }\end{array}$ & & \\
\hline $\begin{array}{l}25 \\
30 \\
35\end{array}$ & OLIGOCENE & $\begin{array}{l}\text { Late } \\
\text { Early }\end{array}$ & Crocker & $\begin{array}{lr}\text { Thick } & \text { sandstone unit } \\
\text { and } & \text { Interbedded }\end{array}$ \\
\hline $\begin{array}{l}40 \\
45 \\
50 \\
55\end{array}$ & EOCENE & $\begin{array}{l}\text { Late } \\
\text { Middle } \\
\text { Early }\end{array}$ & & $\begin{array}{l}\text { unit } \\
\text { unituster dilu stlde }\end{array}$ \\
\hline
\end{tabular}

Fig. 2 Stratigraphic column showing the rock units in study area.

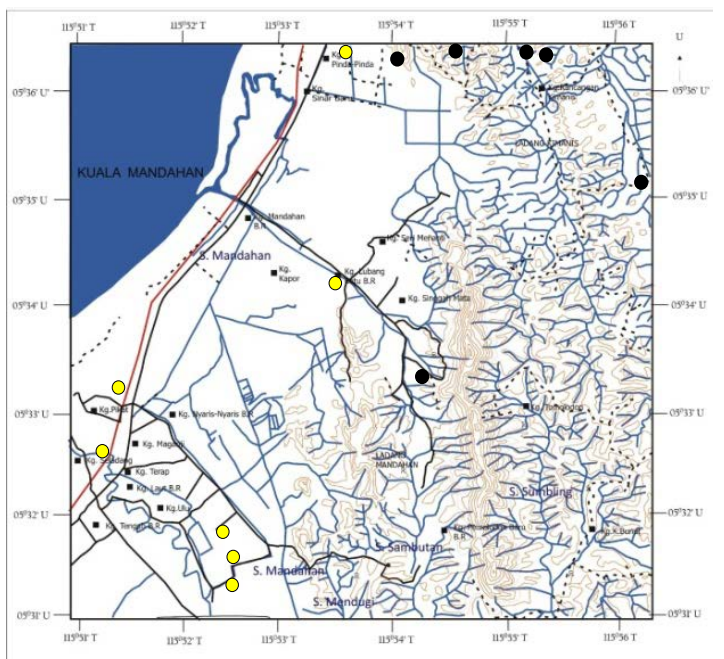

- Soil of Crocker Formation

- Quaternary Deposits

Fig. 3 Location study area and sampling stations. 
$\mathrm{A}=$ concentration obtained from ICP-OES

$\mathrm{V}=$ volume of solution in bottle

$\mathrm{dF}=$ dilution factor

$\mathrm{m}=$ weight of soil sample $(10 \mathrm{~g})$

\subsection{Physico-chemical Test}

Physico-chemical analyses on soil samples were done by $\mathrm{pH}$ test, moisture content, organic content and particle size distribution. $\mathrm{pH}$ values were determined using digital electrometer where $10 \mathrm{~g}$ soil added to $25 \mathrm{ml}$ distilled water and stirred, after 30 minutes $\mathrm{pH}$ reading was taken.

Moisture content test was done by preparing $20 \mathrm{~g}$ of soil sample in a beaker placed overnight in oven with the temperature between $105^{\circ} \mathrm{C}-110^{\circ} \mathrm{C}$. Then the sample weight was taken and the moisture content was determined using the formula:

Moisture content $=\frac{\mathrm{m}_{2}-\mathrm{m}_{3}}{\mathrm{~m}_{3}-\mathrm{m}_{1}} \times 100$

$\mathrm{m}_{1}$ = weight of beaker

$\mathrm{m}_{2}=$ weight of beaker + wet sample

$\mathrm{m}_{3}=$ weight of beaker + dry sample

Dry soil sample was placed in furnace with temperature of $400^{\circ} \mathrm{C}$ for 24 hours and then weight to get its organic matter content using the formula:

Organic matter content $=\frac{\mathrm{m}_{2}-\mathrm{m}_{3}}{\mathrm{~m}_{3}-\mathrm{m}_{1}} \times 100$
$\mathrm{~m}_{1}=$ weight of beaker
$\mathrm{m}_{2}=$ weight of beaker + dry sample
$\mathrm{m}_{3}=$ weight of beaker + dry sample from furnace

\section{RESULTS \& DISCUSSION}

\subsection{Physico-chemical Properties}

Table 1 shows the results of soil physical-chemical properties. Both soil samples were acidic with $\mathrm{pH}$ values range from 3.06 - 5.65 where soils from Crocker Formation were more acidic with the average value of 4.21 than 5.09 in Quaternary deposits. Acidic soil in the study area may be resulted by the leaching process of clay minerals and degradation of plants and organisms [5].

Organic matter content was low in both soil samples. Crocker Formation ranges from $0.98 \%$ to $5.60 \%$ and in Quaternary deposits 2.03\% to 7.63\%. The average value of moisture content in Crocker Formation was $25.11 \%$ and moderately high in Quaternary deposit with the percentage of $37.92 \%$.

Soil classification was determined by the percentage of sand, silt and clay particles. Soil samples from Crocker Formation were classified as sandy clay loam (SC3, SC4) and the rest were sandy loam. While, soil samples of Quaternary deposits classified into sand, sandy loam, sand with loam, clay with loam and sandy clay loam.

\subsection{Heavy Metals Distribution}

Table 3 and Table 4 show the result of $\mathrm{Cr}, \mathrm{Cu}, \mathrm{Pb}$ and $\mathrm{Zn}$ concentrations in soil samples of Crocker Formation and Quaternary deposits respectively. Zn shows the highest concentrations in all soil samples followed by $\mathrm{Cu}$ and $\mathrm{Pb}$ while the lowest was $\mathrm{Cr}$ element. The average value of $\mathrm{Zn}$ concentration in Crocker Formation was $80.24 \mu \mathrm{g} / \mathrm{g}$, and $47.00 \mu \mathrm{g} / \mathrm{g}$ in Quaternary deposits. Cu was recorded 36.60 $\mu \mathrm{g} / \mathrm{g}$ in samples from Crocker Formation and lower in Quaternary Deposits with the average of $7.57 \mu \mathrm{g} / \mathrm{g}$, meanwhile $\mathrm{Pb}$ concentration was $14.73 \mu \mathrm{g} / \mathrm{g}$ in Crocker Formation and $7.87 \mu \mathrm{g} / \mathrm{g}$ in soil of Quaternary deposits. The lowest element concentration was $\mathrm{Cr}$ with the average of $13.17 \mu \mathrm{g} / \mathrm{g}$ in soil sample collected from the Crocker Formation and $5.64 \mu \mathrm{g} / \mathrm{g}$ in Quaternary deposits. Most of the concentrations were recorded high in soil samples of Crocker Formation.

Significant value of $\mathrm{Zn}$ and $\mathrm{Cu}$ elements detected in soil samples of Crocker Formation where $\mathrm{Zn}$ has the highest concentration of $274.36 \mu \mathrm{g} / \mathrm{g}$ in sample SC6 and 127.82 $\mu \mathrm{g} / \mathrm{g}$ in SC7. Highest $\mathrm{Cu}$ was recorded in sample SC1 with the concentration of $127.98 \mu \mathrm{g} / \mathrm{g}$. Table 5 shows the normal range and critical values of metals in soils [1]. Critical values refer to the presence of toxic effects above those concentrations [6]. Soil samples of SC6 and SC7 which show high Zn falls under the critical concentration in soil. The other elements were under normal range in soils.

High concentration of these heavy metals in the study area was controlled by their mobility and leaching process during chemical weathering and also adsorption by clay minerals and organic matter [5]. Other factor controlling the high concentration of heavy metals in Crocker Formation especially $\mathrm{Pb}$ was believe to be generated by human activities as the sampling stations were located at oil palm field and near to residences. It is because soils act as a sink for anthropogenic lead, and the main sources of this metal are well characterized, the most important being mining and metallurgical works, manure and wastewater sludge used in agriculture and also car exhaust [7].

\subsection{Correlation between Heavy Metals to Moisture, Organic Matter and pH}

Figure 4 shows the correlation between moisture content and heavy metals on all soil samples. $\mathrm{Cr}$ and $\mathrm{Zn}$ concentrations increased as the moisture content gets higher. While, $\mathrm{Cu}$ and $\mathrm{Pb}$ concentrations decreases when the soils moisture increased. When organic matter and $\mathrm{pH}$ were correlated with the heavy metals concentrations as shown in Figure 5 and Figure 6, $\mathrm{Cr}$ and $\mathrm{Zn}$ elements were observed to have positive correlation. The other elements, $\mathrm{Cu}$ and $\mathrm{Pb}$ show decreasing concentrations as organic matter and $\mathrm{pH}$ values gets higher in soils, which means that both this elements tends to accumulate more in acidic soil. Soil pH plays an important role: as $\mathrm{pH}$ diminishes lead solubility increases, especially in soils with good ventilation, where oxides predominate [7]. 
Table 1 Physical properties of soil samples from Crocker Formation

\begin{tabular}{|c|c|c|c|c|c|c|c|}
\hline \multirow{2}{*}{ Sample } & \multirow{2}{*}{$\begin{array}{l}\text { Moisture } \\
\text { Content, } \\
\text { Wo (\%) }\end{array}$} & \multirow{2}{*}{$\begin{array}{l}\text { Organic } \\
\text { Matter, } \\
\text { OM (\%) }\end{array}$} & \multirow{2}{*}{$\mathrm{pH}$} & \multicolumn{3}{|c|}{ Particle Size (\%) } & \multirow{2}{*}{$\begin{array}{c}\text { Soil } \\
\text { Classification }\end{array}$} \\
\hline & & & & Sand & Silt & Clay & \\
\hline SC1 & 21.97 & 3.03 & 4.00 & 69.33 & 19.29 & 11.38 & Sandy lom \\
\hline SC2 & 29.59 & 1.80 & 4.80 & 70.27 & 21.62 & 8.11 & Sandy lom \\
\hline SC3 & 33.06 & 3.63 & 5.60 & 56.30 & 22.41 & 21.28 & Sandy clay lom \\
\hline SC4 & 29.45 & 5.60 & 3.06 & 47.22 & 43.80 & 8.97 & Sandy clay lom \\
\hline SC5 & 26.45 & 3.62 & 4.40 & 58.23 & 26.41 & 15.37 & Sandy lom \\
\hline SC6 & 13.81 & 1.56 & 4.12 & 53.54 & 26.55 & 19.91 & Sandy lom \\
\hline SC7 & 21.44 & 0.98 & 3.46 & 56.75 & 23.29 & 19.96 & Sandy lom \\
\hline Range & $\begin{array}{r}13.81- \\
33.06 \\
\end{array}$ & $\begin{array}{r}0.98- \\
5.60 \\
\end{array}$ & $\begin{array}{r}3.06- \\
5.60 \\
\end{array}$ & & & & \\
\hline Average & 25.11 & 2.89 & 4.21 & & & & \\
\hline
\end{tabular}

Table 2 Physical properties of soil samples from Quaternary deposit

\begin{tabular}{|c|c|c|c|c|c|c|c|}
\hline \multirow{2}{*}{ Sample } & \multirow{2}{*}{$\begin{array}{l}\text { Moisture } \\
\text { Content, } \\
\text { Wo (\%) } \\
\end{array}$} & \multirow{2}{*}{$\begin{array}{l}\text { Organic } \\
\text { Matter, } \\
\text { OM (\%) }\end{array}$} & \multirow{2}{*}{$\mathrm{pH}$} & \multicolumn{3}{|c|}{ Particle Size (\%) } & \multirow{2}{*}{$\begin{array}{c}\text { Soil } \\
\text { Classification }\end{array}$} \\
\hline & & & & Sand & Silt & Clay & \\
\hline SQ1 & 38.06 & 3.82 & 4.90 & 95.01 & 1.84 & 3.15 & Sand \\
\hline SQ2 & 19.24 & 2.14 & 4.54 & 63.63 & 24.87 & 11.50 & Sandy loam \\
\hline SQ3 & 53.56 & 2.03 & 5.32 & 72.82 & 10.11 & 17.07 & Sandy loam \\
\hline SQ4 & 25.34 & 6.96 & 5.65 & 84.26 & 5.90 & 9.84 & Sand with loam \\
\hline SQ5 & 60.51 & 7.63 & 4.62 & 35.56 & 31.03 & 33.41 & Clay with loam \\
\hline SQ6 & 26.86 & 2.32 & 5.61 & 54.10 & 42.69 & 3.22 & Sandy loam \\
\hline SQ7 & 41.88 & 7.28 & 4.96 & 50.17 & 25.53 & 24.29 & Sandy clay loam \\
\hline Range & $\begin{array}{r}19.24- \\
60.51 \\
\end{array}$ & $\begin{array}{r}2.03- \\
7.63 \\
\end{array}$ & $\begin{array}{r}4.54- \\
5.65 \\
\end{array}$ & & & & \\
\hline Average & 37.92 & 4.60 & 5.09 & & & & \\
\hline
\end{tabular}

Table 3 Distribution of heavy metals in soil samples from Crocker Formation

\begin{tabular}{|c|r|r|r|r|}
\hline $\begin{array}{c}\text { Element } \\
\text { Sample }\end{array}$ & \multicolumn{1}{c|}{$\begin{array}{c}\mathrm{Cr} \\
\mu \mathrm{g} / \mathrm{g}\end{array}$} & \multicolumn{1}{c|}{$\begin{array}{c}\mathrm{Cu} \\
\mu \mathrm{g} / \mathrm{g}\end{array}$} & \multicolumn{1}{c|}{$\begin{array}{c}\mathrm{Pb} \\
\mu \mathrm{g} / \mathrm{g}\end{array}$} & \multicolumn{1}{c|}{$\begin{array}{c}\mathrm{Zn} \\
\mu \mathrm{g} / \mathrm{g}\end{array}$} \\
\hline SC1 & 4.23 & 127.98 & 8.54 & 2.59 \\
\hline SC2 & 11.03 & 16.94 & 17.31 & 48.15 \\
\hline SC3 & 16.36 & 3.10 & 1.47 & 47.29 \\
\hline SC4 & 6.56 & 2.44 & 29.50 & 21.90 \\
\hline SC5 & 20.11 & 4.13 & 3.13 & 39.59 \\
\hline SC6 & 16.79 & 42.76 & 26.92 & 274.36 \\
\hline SC7 & 17.08 & 58.82 & 16.26 & 127.82 \\
\hline Range & $4.23-20.11$ & $2.44-127.98$ & $1.47-29.50$ & $2.59-274.36$ \\
\hline Average & 13.17 & 36.60 & 14.73 & 80.24 \\
\hline
\end{tabular}


Pungut et al. / Malaysian Journal of Fundamental and Applied Sciences Vol. 9, No.4 (2013) 185-190

Table 4 Distribution of heavy metals in soil samples from Quaternary deposit

\begin{tabular}{|c|r|r|r|r|}
\hline $\begin{array}{c}\text { Element } \\
\text { Sample }\end{array}$ & \multicolumn{1}{c|}{$\begin{array}{c}\mathrm{Cr} \\
\mu \mathrm{g} / \mathrm{g}\end{array}$} & \multicolumn{1}{c|}{$\begin{array}{c}\mathrm{Cu} \\
\mu \mathrm{g} / \mathrm{g}\end{array}$} & \multicolumn{1}{c|}{$\begin{array}{c}\mathrm{Pb} \\
\mu \mathrm{g} / \mathrm{g}\end{array}$} & \multicolumn{1}{c|}{$\begin{array}{c}\mathrm{Zn} \\
\mu \mathrm{g} / \mathrm{g}\end{array}$} \\
\hline SQ1 & 0.64 & 1.49 & 1.74 & 58.57 \\
\hline SQ2 & 8.50 & 12.40 & 11.01 & 62.39 \\
\hline SQ3 & 3.62 & 6.46 & 9.34 & 55.65 \\
\hline SQ4 & 1.06 & 2.33 & 1.95 & 22.95 \\
\hline SQ5 & 11.01 & 13.85 & 14.18 & 50.52 \\
\hline SQ6 & 8.26 & 9.66 & 7.64 & 32.83 \\
\hline SQ7 & 6.40 & 6.81 & 9.22 & 46.10 \\
\hline Range & $0.64-11.01$ & $1.49-13.85$ & $1.74-14.18$ & $22.95-62.39$ \\
\hline Average & 5.64 & 7.57 & 7.87 & 47.00 \\
\hline
\end{tabular}

Table 5 Normal range and critical concentrations of metal in soils [1]

\begin{tabular}{ccc} 
Metal & $\begin{array}{c}\text { Normal range in soils } \\
(\mathrm{mg} \mathrm{kg}-1)\end{array}$ & $\begin{array}{c}\text { Critical concentration in soils } \\
(\mathrm{mg} \mathrm{kg}-1)\end{array}$ \\
\hline $\mathrm{Cu}$ & $2.00-250$ & $60-125$ \\
$\mathrm{~Pb}$ & $2.00-300$ & $100-400$ \\
$\mathrm{Zn}$ & $1.00-900$ & $70-400$ \\
\hline
\end{tabular}

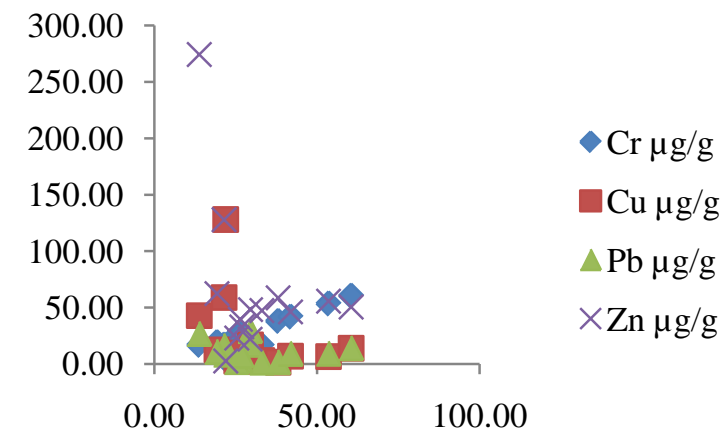

Fig.4 Correlation of moisture content and $\mathrm{Cu}, \mathrm{Cr}, \mathrm{Pb}$ and $\mathrm{Zn}$ in soil samples.

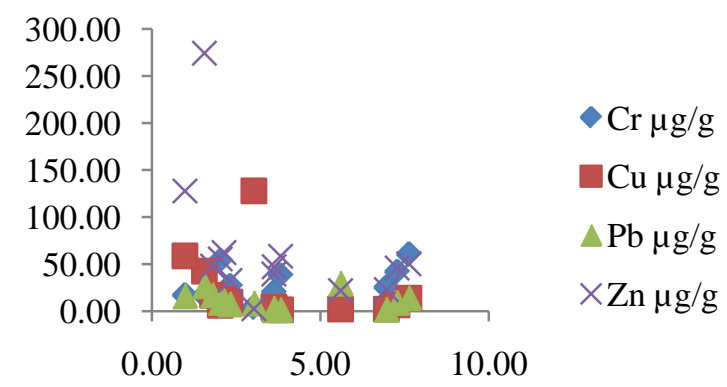

Fig. 5 Correlation of organic matter content and $\mathrm{Cu}, \mathrm{Cr}, \mathrm{Pb}$ and $\mathrm{Zn}$ in soil samples. 


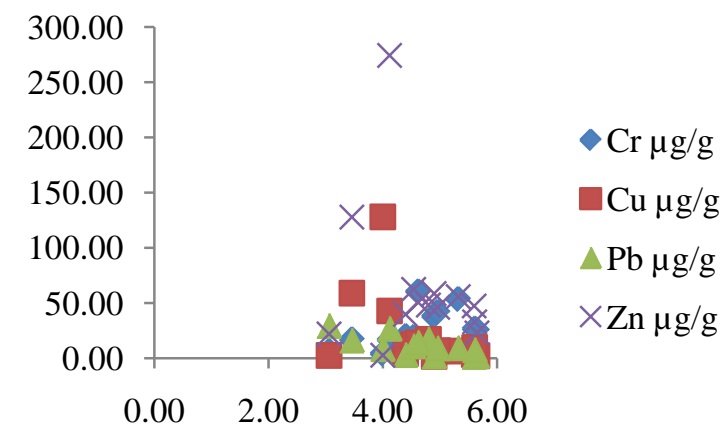

Fig.6 Correlation of $\mathrm{pH}$ and $\mathrm{Cu}, \mathrm{Cr}, \mathrm{Pb}$ and $\mathrm{Zn}$ in soil samples.

\section{CONCLUSION}

In the study area the highest distribution of heavy metals was $\mathrm{Zn}$ followed by $\mathrm{Cu}, \mathrm{Pb}$ and $\mathrm{Cr}$ in all soil samples where, soils from Crocker Formation have higher value than soils of Quaternary deposits. The significantly high value of $\mathrm{Zn}$ and $\mathrm{Cu}$ recorded in soil samples of Crocker Formation was due to their mobility and leaching process and also by adsorption by clay and organic matter. Human activities also contributed to the high concentration of $\mathrm{Cu}, \mathrm{Pb}$ and $\mathrm{Zn}$. The physical properties of the soils (organic content, moisture, $\mathrm{pH}$ and clay particles) also controlled the presence of heavy metals.

\section{ACKNOWLEDGEMENT}

Author would like to thank Universiti Malaysia Sabah for funding the study.

\section{REFERENCES}

[1] B.J., Alloway. Heavy Metals in Soils. Blackie Academic and Professional, London, U.K. 1995.

[2] K. B. Mmolawa, A. S. Likuku and G. K. Gaboutloeloe. African Journal of Environmental Science and Technology. 5(3) (2011) 186-196.

[3] C. Njofang, J. Matschullat, J.P. Tchouankoue and A. Amougou, Pakistan Journal of Biological Sciences 10(18) (2007) 3048-3056,

[4] Sanudin Hj. Tahir and Baba Musta, Pengenalan kepada Stratigrafi, Penerbit Universiti Malaysia Sabah, Kota Kinabalu, 2007.

[5] Baba Musta, Hennie Fitria W. Soehady E. and Hazerina Pungut, Proceedings of National Geoscience Conference 2011.

[6] J.M., Bowen. Environmental Chemistry of the Elements, Academic Press, London. 1979.

[7] M.J. Martinez Garcia, S. Moreno-Grau, J.J. Martinez Garcia, J. Moreno, J. Bayo, J.J. Guillen Perez and J. Moreno-Clavel, Water, Air and Soil Pollution, Kluwer Academic Publishers, Netherlands, 2001. 